\title{
EVOLUTIONARY STABILITY OF LINGUISTIC POLITENESS AND THE POLITENESS EQUILIBRIUM PRINCIPLE
}

\author{
Roland Mühlenbernd ${ }^{1}$, Przemysław Żywiczyński ${ }^{* 2}$, and Sławomir Wacewicz ${ }^{2}$ \\ *Corresponding Author: przemek@umk.pl \\ ${ }^{1}$ Department of Management, Ca'Foscari University, Venice, Italy \\ ${ }^{2}$ Department of English Studies, Nicolaus Copernicus University, Torun, Poland
}

\section{Introduction}

Unlike many facets of language - phonology, syntax, semantics or even pragmatics - linguistic politeness (LP) has attracted little attention of evolutionarily minded researchers. We think that this lack of interest - apart from a few isolated attempts (van Rooy, 2003; Żywiczyński, 2012; Wacewicz et al., 2015; Pleyer \& Pleyer, 2016) is not dictated by a peripheral status of LP for the description of language, and especially for language evolution. LP is a universal characteristic of languages (cf. Brown \& Levinson, 1987) but its specific markers are subject to considerable cultural variation, a combination of features that makes it an interesting target for evolutionary modeling. Next, LP is first and foremost a set of interactional strategies, and hence naturally lends itself to rendering in game-theoretic terms (cf. Quinley, 2011). In this paper, we take a game-theoretic approach and make a case that LP can be subsumed under a more general explanatory principle: disalignment of interests. This is formally expressed as the Politeness Equilibrium Principle (PEP), whereby the more disalignment there is between the interests of Speaker and Hearer, the more LP Speaker needs to use to offset the imbalance. Furthermore, we present a game-theoretic model to show that the use of LP predicated on the PEP forms an evolutionary stable system.

\section{The Politeness Equilibrium Principle}

Possibly, the main problem of rendering LP into evolutionary terms concerns its operationalization. LP, although admittedly elusive, is in principle measurable; e.g. it can be stated in terms of speech indirectness (Leech, 1983; Brown \& Levinson, 1987), which in turn closely correlates with utterance length (Östman, 1989). Furthermore, following Brown and Levinson (1987), we assume the rationality of a competent Speaker, who is able to strategically increase and decrease the amount of LP in her utterances. Finally, we suggest that the use of LP involves social costs: the more LP Speaker uses, the more cost she has to pay. This point is 
in line with the conceptualization of LP as social commodity (Werkhofer, 2005), whereby using politeness incurs Speaker's payment in the currency of face (Brown \& Levinson, 1987) or respect (Kaplan, 1999).

In the present work, we focus on one type of speech act: request. In this regard, we assume that Speaker follows the following principle:

Politeness Equilibrium Principle (PEP): The amount of linguistic politeness Speaker uses in a request corresponds negatively to the alignment of interests ${ }^{1}$ between Speaker and Hearer: the less aligned the interests are in favor of Speaker, the more linguistic politeness she uses.

\section{The PPL model}

Based on a principle in animal communication ${ }^{2}$ (Johnstone, 1997; Zahavi \& Zahavi, 1997; Searcy \& Nowicki, 2005), we developed a game-theoretic model (PEP model) that shows that the strategic use of LP according to the PEP forms an evolutionarily stable system (Maynard Smith, 1982), but only under the following conditions: i) the usage of LP involves substantial costs (of social nature), ii) Speaker is rational in that she wants to maximize her payoff, defined as the difference between her expected utility of getting the request granted by Hearer and the costs involved, and iii) the disalignment of interests (reflecting how big a favor is being requested) does not exceed a particular degree: there are requests that Hearer will never grant, no matter how much LP Speaker uses. This last point is in line with more general theoretical work on game-theoretic signaling models that shows that signaling systems are not evolutionary stable when the magnitude of disaligment between Speaker and Hearer is too large (Crawford \& Sobel, 1982).

\section{Outlook}

The PEP model is only a first step towards understanding the evolutionary stability of LP, and further work is necessary to make the model more complete. Most importantly, this includes taking into account other key variables that determine the amount of LP used in a request, such as social distance, power, or cultural competence. Furthermore, while the current version of the PEP model focuses on strategic behavior of Speaker, a more complete model will also take the strategic behavior of Hearer into consideration.

\footnotetext{
${ }^{1}$ Note: In Politeness theory the role of alignment of interests was already discussed as a factor for the choice of LP in requests, termed by Brown and Levinson (1987) as Rate of Imposition.

${ }^{2}$ This principle follows the pattern: 'the more an individual needs, the more intensive is its signal' and can e.g. be found in food begging of offspring of birds (cf. Searcy \& Nowicki, 2005, Fig. 1.2).
} 


\section{References}

Brown, P., \& Levinson, S. (1987). Politeness: Some universals in language usage. Cambridge: Cambridge University Press.

Crawford, V. P., \& Sobel, J. (1982). Strategic information transmission. Econometrica, 50, 1431-1451.

Johnstone, R. A. (1997). The evolution of animal signals. In J. R. Krebs \& N. B. Davies (Eds.), Behavioural ecology (pp. 155-78). Oxford: Blackwell.

Kaplan, D. (1999). What is meaning? explorations in the theory of meaning as use. brief version - draft 1. University of California, Los Angeles.

Leech, G. (1983). The principles of pragmatics. London: Longman.

Maynard Smith, J. (1982). Evolution and the theory of games. Cambridge University Press.

Östman, J.-O. (1989). Testing iconicity: Sentence structure and politeness. Belgian Journal of Linguistics, 4, 145-163.

Pleyer, M., \& Pleyer, M. (2016). The evolution of im/politeness. In S. Roberts, C. Cuskley, L. McCrohon, L. Barceló-Coblijn, O. Fehér, \& T. Verhoef (Eds.), The evolution of language: Proceedings of the 11th international conference (evolang11).

Quinley, J. (2011). Politeness and trust games. In D. Lassiter (Ed.), Proceedings of the 2011 esslli student session (pp. 143-151). Stanford University.

van Rooy, R. (2003). Being polite is a handicap: Towards a game theoretical analysis of polite linguistic behavior. In Tark: Proceedings of the $9^{\text {th }}$ conference on theoretical aspects of rationality and knowledge (pp. 45-58). New York: ACM.

Searcy, W., \& Nowicki, S. (2005). The evolution of animal communication: Reliability and deception in signaling systems. Princeton/Oxford: Princeton University Press.

Wacewicz, S., Żywiczyński, P., \& McCrohon, L. (2015). Linguistic politeness from an ethological perspective: Theoretical questions and empirical issues. Theoria et Historia Scientiarum, 11, 81-98.

Werkhofer, K. (2005). Traditional and modern views: The social constitution and power of politeness. In R. Watts, S. Ide, \& K. Ehlich (Eds.), Politeness in language: Studies in its history, theory and practice (pp. 155-199). Berlin: De Gruyter Mouton.

Zahavi, A., \& Zahavi, A. (1997). The handicap principle: A missing piece of darwin's puzzle. New York: Oxford University Press.

Żywiczyński, P. (2012). An attempt at a proxemic description of politeness from the ethological-evolutionary perspective. Theoria et Historia Scientiarum, 9, 71-98. 